\title{
Blood transfusion service in Poland in 2019
}

\author{
Aleksandra Rosiek@, Anna Tomaszewska®, Jolanta Antoniewicz-Papis®®, \\ Elżbieta Lachert(i), Magdalena Łętowska (i)
}

Department of Transfusion Medicine, Institute of Hematology and Transfusion Medicine in Warsaw

\begin{abstract}
Summary
Background: In this study we evaluated the basic aspects of the activity of the Polish Blood Transfusion Service (hereinafter referred to as Centers) in 2019.

Materials and methods: Retrospective analysis of the 2019-data supplied by the Centers.

Results: In 2019, blood and blood components were collected in 21 Polish Centers and 129 local collection sites as well as during 13048 mobile collections. The overall number of blood donors was estimated at 590 893, the majority of which were non-remunerated donors (590 280 — including 40738 responders to donation appeals), as well as 57 remunerated donors and 556 autologous donors. Most frequent were whole blood collections (1 202 079) and least frequent granulocyte concentrate collections (94) and RBCs collections by apheresis (48 donations). Whole blood was collected mostly in local collection sites (45.25\%), in Centers (28.75\%) and mobile collection sites (26\%). *Most frequently prepared blood components were RBCs - 1180333 units) and fresh frozen plasma (FFP - 1344092 units, 19.28\% dedicated for clinical use). Platelet concentrates (PCs) collected by apheresis amounted to 53379 units and 81905 were whole blood-derived. Additional processing methods (leukocyte depletion, irradiation) were more frequently applied to PCs (43.34\% leukocyte-depleted, $0.04 \%$ irradiated, $54.63 \%$ both leukocyte-depleted and irradiated) than to RBCs (18.71\% leukocyte-depleted, 0.06\% irradiated, 9.17\% both leukocytedepleted and irradiated). Pathogen reduction technologies were applied to 11,97\% of FFP units issued for clinical use (transfusion) and $11.87 \%$ of PCs. In 2019 - for a variety of reasons - 14013 units of whole blood, 32798 units of RBCs, 49285 units of FFP, 1334 units of cryoprecipitate, 4778 units of pooled PCs and 1279 of apheresis PCs were wasted.
\end{abstract}

Conclusions: Our study data may be considered as starting point for assessment of the tendencies observed in the Polish blood transfusion service and may serve practical-benchmarking with benefit to the transfusion community as a whole.

\section{Key words: blood donors, blood donation, blood components}

J. Transf. Med. 2020; 13: 212-227

\section{Introduction}

This is our twelfth presentation of selected issues related to the annual activities of the public blood service in Poland. In particular, the following topics were discussed for the year 2019: the number of donors, the number of donations, the collection sites for whole blood and blood components, including red blood cell concentrate (RBC), fresh frozen plasma (FFP), platelet cell concentrate (KKP) and granulocyte concentrate (KG). We also discussed the issues related to the use of some additional preparation methods as well as the inactivation of biological pathogens in

Correspondence address: dr n. med. Aleksandra Rosiek, Department of Transfusion Medicine, Institute of Hematology and Transfusion Medicine in Warsaw, Indiry Gandhi Street 14, 02-776 Warsaw, phone: (22) 34963 91, fax: (22) 349 63 76,

e-mail: arosiek@ihit.waw.pl

Translation: mgr Krystyna Dudziak

*The data initially presented in the article included 28760 units of inactivated FFP sent outside the territory of Poland in 2019 . If the units are disregarded (as should be) the statistical data change and the changes are marked with greyshadow in appropriate places of the text and the tables. 
labile blood components. The scale and the most common causes of waste of blood components were also explored and analyzed.

The activity of Polish BTS is regulated by the Public Blood Transfusion Service Act voted by the Polish Parliament on August 22 nd, 1997 [1]. Pursuant to this act, the following units of the public blood transfusion service are entitled to collect blood and prepare blood components: 21 Centers as well as the Military Blood Transfusion Center (supervised by the Ministry of Defense) and the Blood Transfusion Center of the Ministry of Internal Affairs and Administration. The activity of BTS in Poland is supervised by the Polish Ministry of Health and the Institute of Hematology and Transfusion Medicine (IHTM) has substantive supervision over all the public blood service units mentioned above.

\section{Materials and methods}

As in the previous years, this study relies on data provided by 21 Centers in form of annual reports. To the aim of standardization of the forwarded data, IHTM together with the National Blood Centre (NCK) created a template of definitions.

First-time donor - donates blood during the reporting period but has never before donated blood for medical purposes.

Multiple (regular) donor - systematically donates blood (at least twice during the last 24 months).

Multiple repeat donor - donates blood again more than 2 years after the last donation.

Non remunerated donor - receives no financial compensation for donated blood/blood component at least once during the reporting period.

Remunerated donor - receives financial compensation for every donation during the reporting period.

Responder to donation appeal - donates blood/blood component following emergency appeal for donation at least once during the reporting period (the term also applies to former „family donors").

Directed donor - donates blood for a specific patient at least once during the reporting period.

Autologous donor - donates blood/blood component for himself at least once during the reporting period.

Donation - whole blood or blood component collected by apheresis, including blood for clinical and scientific purposes collected from immunized and family donors etc.
Unit (u.) - volume of anticoagulated whole blood obtained from $450 \mathrm{ml}$ of blood collected from the donor or volume of blood component obtained from one unit of anticoagulated whole blood.

Unit of plasma - volume of plasma obtained from whole blood or by automated plasmapheresis. One automated plasmapheresis procedure provides 3 units of plasma $(600 \mathrm{ml})$.

Unit of PC from apheresis - platelets obtained from a single donor with cell separator (1 donation regardless of platelet count).

Therapeutic dose of $\mathbf{P C}-\mathrm{PCs}$ (either pooled or from apheresis) dedicated for an adult; according to current guidelines it contains $\geq 3 \times 10^{11}$ platelets.

\section{Results}

\section{Regional Blood Transfusion Centers (Centers)}

In 2019 there were 21 Centers and 129 local collection sites operating in Poland, which is three local collection sites less than in 2018 . In addition, 13,048 mobile collections were performed which is 141 less than in the past year. The mobile collections were organized by all Centers in 2019. As in previous years, the largest number of mobile collections were organized by the Center in Katowice $(1,875)$. Over 1000 mobile collection teams were organized by the Center in Łódź (1031), Wałbrzych (1269) and Warsaw (1238). As compared to the previous year, the number of mobile collections decreased in 13 Centers, increased in 7 , and remained unchanged in one (Wałbrzych). The upward trend was markedly higher for the Center in Racibórz (increase by $30.40 \%$ ), and the downward trend - for Gdańsk (decrease by $16.20 \%$ ) (Table 1).

\section{Donors}

In 2019, a total of 692537 persons came to donate blood (in 2018 - 693772). Only 590893 of them were qualified for donation (in $2018-590470$ ). Blood or blood components for clinical use were donated by a total of about $85 \%$ of people who were willing to donate blood (the situation was similar in previous years). The difference was mostly due to donor deferral. In 2019, a total of 8,940 permanent deferrals were applied as well as 234,966 temporary deferrals of 184,644 persons; as in previous years, the most common cause $(73,885$ cases of deferral) was low hemoglobin level. 
Table 1. Mobile collections organized in Polish Regional Blood Transfusion Centers in 2018 and 2019

\begin{tabular}{|c|c|c|c|}
\hline \multirow[t]{2}{*}{ Centers } & \multicolumn{3}{|c|}{ Mobile collections } \\
\hline & 2018 & 2019 & $\begin{array}{c}\text { Increase/ } \\
\text { /decrease as } \\
\text { compared to } \\
2018\end{array}$ \\
\hline Białystok & 729 & 728 & $\downarrow$ \\
\hline Bydgoszcz & 816 & 872 & $\uparrow$ \\
\hline Gdańsk & 432 & 362 & $\downarrow$ \\
\hline Kalisz & 416 & 425 & $\uparrow$ \\
\hline Katowice & 1949 & 1875 & $\downarrow$ \\
\hline Kielce & 285 & 283 & $\downarrow$ \\
\hline Kraków & 833 & 793 & $\downarrow$ \\
\hline Lublin & 337 & 404 & $\uparrow$ \\
\hline Łódź & 1197 & 1031 & $\downarrow$ \\
\hline Olsztyn & 507 & 494 & $\downarrow$ \\
\hline Opole & 271 & 229 & $\downarrow$ \\
\hline Poznań & 851 & 877 & $\uparrow$ \\
\hline Racibórz & 250 & 326 & $\uparrow$ \\
\hline Radom & 325 & 393 & $\uparrow$ \\
\hline Rzeszów & 240 & 229 & $\downarrow$ \\
\hline Słupsk & 164 & 159 & $\downarrow$ \\
\hline Szczecin & 397 & 422 & $\uparrow$ \\
\hline Wałbrzych & 1269 & 1269 & no change \\
\hline Warszawa & 1243 & 1238 & $\downarrow$ \\
\hline Wrocław & 383 & 371 & $\downarrow$ \\
\hline Zielona Góra & 295 & 268 & $\downarrow$ \\
\hline Total & 13189 & 13048 & $\downarrow$ \\
\hline
\end{tabular}

$\downarrow$ - decrease as compared to 2018; $\uparrow$ — increase as compared to 2018

Donors were mostly voluntary unremunerated (590,280 people - including 40738 responders to appeal and 111 directed donors). In 2019, blood and blood components were also donated by 57 remunerated and 556 autologous donors.

In 13 Centers blood was donated only by voluntary unremunerated donors. The highest number of remunerated donors (40) was reported in the Center in Poznań.

Among donors of blood and blood components there were 136,715 first-time donors $(23.14 \%)$, 375,911 multiple regular donors $(63.62 \%)$ and 78,267 multiple repeat donors (13.25\%).

10 Centers reported a decrease in the number of donors while 11 noted an increase. As compared to 2018 , the largest increase in the number of donors was recorded in the Centers in Radom (by $10.13 \%$ ) and Kalisz (by 3.54\%). Table 2 presents the number of donors in each Center in 2019.
As in previous years, the most numerous group of blood donors were people aged 18 to 44 (508,889; 144,324 women and 364,565 men).

\section{Donations}

In 2019, whole blood was collected most frequently (1,202,079 donations), while the least frequent were collections of: granulocyte concentrate (94 donations at 5 Centers) and RBC obtained by apheresis ( 48 donations in 3 Centers). As in previous years, the largest number of whole blood donations was reported by the Centers in Katowice (117 739) and Warsaw (113 895). Apheresis was mainly used for preparation of PCs (17 736 donations) and plasma (42 386 donations). The greatest number of apheresis plasma donations was reported by the Center in Kalisz $(9,464)$, and PC donations by apheresis - at Center in Katowice $(5,537)$.

Automated donations of a combination of blood components (mostly PC and plasma - 28,966 donations) were also collected, mostly in the Center in Warsaw (9,79 donations). Less frequent were the combined collections of PCs and RBCs (83), mostly in the Center in Wrocław (69 donations).

Table 3 presents the number of complete donations of blood components in 2019.

Blood was collected primarily in the local collection sites (45.25\% of whole blood donations), less frequently at the Center premises (28.75\%), and during mobile collections (26\%). As in the previous years, most of the whole blood donations - 59.46\% — was collected during mobile collections organized by the Center in Wałbrzych. Table 4 provides a list of whole blood collection sites in 2019.

\section{Blood components}

\section{Red Blood cells (RBCs)}

Donated blood was processed into blood components, mostly RBC (a total of 1,180,333 units), which represented a slight country-wide increase as compared to the previous year (1,161,600 units). As in previous years, the largest amount of RBC were obtained in the Centers in Katowice and Warsaw (116,513 units and 113,639 units, respectively) (Table 5). The largest increase in the number of $\mathrm{RBC}$ units was recorded in Radom (by 9.88\%) and in Warsaw (by $4.90 \%$ ). A decrease was reported by 6 Centers and an increase by 15 .

Some RBC units were subjected to additional preparation the most common of which were leukocyte reduction and irradiation. 
Table 2. Blood donors in Polish Regional Blood Transfusion Centers (2019)

\begin{tabular}{|c|c|c|c|c|c|}
\hline \multirow[t]{2}{*}{ Centers } & \multicolumn{4}{|c|}{ Donors } & \multirow{2}{*}{$\begin{array}{l}\text { Increase/decrease as } \\
\text { compared to } 2018\end{array}$} \\
\hline & First-time & Multiple regular & Multiple repeat & Total & \\
\hline Białystok & 5168 & 20709 & 3736 & 29613 & $\uparrow$ \\
\hline Bydgoszcz & 8034 & 22861 & 4836 & 35731 & $\uparrow$ \\
\hline Gdańsk & 5877 & 18197 & 3781 & 27855 & $\downarrow$ \\
\hline Kalisz & 4699 & 13964 & 2680 & 21343 & $\uparrow$ \\
\hline Katowice & 10493 & 34411 & 6414 & 51318 & $\uparrow$ \\
\hline Kielce & 5106 & 10429 & 2878 & 18413 & $\uparrow$ \\
\hline Kraków & 10440 & 28525 & 5633 & 44598 & $\downarrow$ \\
\hline Lublin & 7216 & 17390 & 3675 & 28281 & $\uparrow$ \\
\hline Łódź & 9993 & 18636 & 6374 & 35003 & $\uparrow$ \\
\hline Olsztyn & 5439 & 13817 & 1171 & 20427 & $\downarrow$ \\
\hline Opole & 2462 & 8870 & 1868 & 13200 & $\downarrow$ \\
\hline Poznań & 9362 & 31720 & 6419 & 47501 & $\downarrow$ \\
\hline Racibórz & 1914 & 9795 & 1798 & 13507 & $\downarrow$ \\
\hline Radom & 3800 & 7099 & 1977 & 12876 & $\uparrow$ \\
\hline Rzeszów & 5508 & 20708 & 3146 & 29362 & $\uparrow$ \\
\hline Słupsk & 2930 & 6625 & 1111 & 10666 & $\downarrow$ \\
\hline Szczecin & 5735 & 15408 & 3048 & 24191 & $\downarrow$ \\
\hline Wałbrzych & 2545 & 8192 & 1406 & 12143 & $\uparrow$ \\
\hline Warszawa & 16840 & 35959 & 9068 & 61867 & $\uparrow$ \\
\hline Wrocław & 8658 & 24347 & 5123 & 38128 & $\downarrow$ \\
\hline Zielona Góra & 4496 & 8249 & 2125 & 14870 & $\downarrow$ \\
\hline Total & 136715 & 375911 & 78267 & 590893 & $\uparrow$ \\
\hline
\end{tabular}

$\downarrow$ - decrease as compared to 2018; $\uparrow$ - increase as compared to 2018

In 2019, a total of 220,864 units of leucocyte-depleted RBCs was obtained (18.71\% of all RBC), as well as 108,178 units of leucocyte-depleted irradiated $\mathrm{RBCs}(9.17 \%)$. $\mathrm{RBC}$ irradiation only was used sporadically, yielding 729 units of irradiated RBCs $(0.06 \%)$.

Country-wide $27.88 \%$ of all RBCs (in 2018 $-26.23 \%$ ) were subjected to leuko-reduction and $9.23 \%$ to irradiation (in $2018-9.25 \%$ ). Table 6 presents the number of leukocyte depleted and irradiated units of RBCs obtained by each Center in 2019.

\section{Platelet concentrate}

Platelet concentrate (PC) was the second most frequently prepared blood component, just like in the years before. Two basic methods were used for $\mathrm{PC}$ preparation:

- centrifugation of whole blood from traditional donations, and - if necessary - pooling of several units of the $\mathrm{PC}$ to obtain pooled $\mathrm{PC}$. In some Centers automated methods were used;
- apheresis with cell separators (some of the PC units obtained with this method were divided into smaller therapeutic doses).

In 2019 , a total of 81,905 pooled $\mathrm{PC}$ units were prepared (in 2018 - 83,598), including 56,733 from buffy coat with manual method, and 25,172 with automated methods.

In 2019, a total of 53,379 PCs were obtained by apheresis $(39.46 \%$ of all units for clinical use (in $2018-37.54 \%$ ).

As in the previous years, the highest number of PCs from whole blood was obtained in Poznań (10,021 pooled PC units), while from apheresis in Warsaw $(12,604)$.

The percentage of $\mathrm{PCs}$ from apheresis differed significantly between Centers - from $0.55 \%$ in Zielona Góra to $75.02 \%$ in Warsaw and $78.39 \%$ in Białystok (Table 7).

Some part of PC units were subjected to leukocyte depletion and / or irradiation. PCs collected by apheresis with modern cell separators are usually 
Table 3. Whole blood and apheresis donations in 2019*

\begin{tabular}{|c|c|c|c|c|c|c|c|c|}
\hline \multirow[t]{2}{*}{ Centers } & \multirow[t]{2}{*}{ Whole blood } & \multicolumn{6}{|c|}{ Apheresis } & \multirow[t]{2}{*}{ Total } \\
\hline & & Plasma & RBC & PC & GC & $\begin{array}{c}\mathrm{PC}+ \\
\text { plasma }\end{array}$ & $P C+R B C$ & \\
\hline Białystok & 61902 & 5587 & 0 & 213 & 9 & 1630 & 0 & 69341 \\
\hline Bydgoszcz & 70765 & 5482 & 11 & 986 & 39 & 47 & 0 & 77330 \\
\hline Gdańsk & 60436 & 1383 & 0 & 534 & 0 & 0 & 0 & 62353 \\
\hline Kalisz & 42878 & 9464 & 0 & 0 & 0 & 516 & 0 & 52858 \\
\hline Katowice & 117739 & 51 & 0 & 5537 & 0 & 4680 & 0 & 128007 \\
\hline Kielce & 33743 & 756 & 0 & 903 & 0 & 0 & 0 & 35402 \\
\hline Kraków & 92126 & 39 & 0 & 2199 & 21 & 0 & 0 & 94385 \\
\hline Lublin & 56901 & 3734 & 0 & 0 & 0 & 1688 & 0 & 62323 \\
\hline Łódź & 61451 & 88 & 0 & 781 & 0 & 0 & 0 & 62320 \\
\hline Olsztyn & 42504 & 1402 & 0 & 11 & 0 & 566 & 0 & 44483 \\
\hline Opole & 28987 & 39 & 0 & 601 & 0 & 0 & 0 & 29627 \\
\hline Poznań & 96355 & 2653 & 0 & 897 & 0 & 772 & 0 & 100677 \\
\hline Racibórz & 31451 & 1901 & 0 & 0 & 0 & 467 & 0 & 33819 \\
\hline Radom & 24481 & 1274 & 0 & 65 & 0 & 752 & 0 & 26572 \\
\hline Rzeszów & 64394 & 2261 & 0 & 1365 & 0 & 0 & 0 & 68020 \\
\hline Słupsk & 21969 & 724 & 0 & 284 & 0 & 245 & 11 & 23233 \\
\hline Szczecin & 49375 & 910 & 0 & 29 & 10 & 2641 & 0 & 52965 \\
\hline Wałbrzych & 27043 & 103 & 7 & 89 & 0 & 32 & 3 & 27277 \\
\hline Warszawa & 113895 & 202 & 0 & 1195 & 15 & 9791 & 0 & 125098 \\
\hline Wrocław & 72058 & 4332 & 30 & 2047 & 0 & 5122 & 69 & 83658 \\
\hline Zielona Góra & 31626 & 1 & 0 & 0 & 0 & 17 & 0 & 31644 \\
\hline Total & 1202079 & 42386 & 48 & 17736 & 94 & 28966 & 83 & 1291392 \\
\hline
\end{tabular}

leucocyte depleted and require no additional leukocyte depletion.

In 2019, a total of 58,633 therapeutic doses of leukocyte reduced PCs were obtained, which accounted for $43.34 \%$ of all PCs obtained as well as 73,905 therapeutic doses of irradiated leukocyte depleted PCs (54.63\%). PC irradiation alone was used sporadically to give 53 therapeutic units of the irradiated blood component $(0.04 \%$ of all prepared PC therapeutic units).

Country-wide, $97.97 \%$ of all PC therapeutic doses were leukocyte depleted and $-54,67 \%$ were irradiated (in 2018, 90.64\% and 59.44\%, respectively).

Table 8 presents the numbers of leukocyte depleted and irradiated PCs obtained by each Center in 2019.

In 2019 a total of 129,301 therapeutic doses of PC were issued for clinical purposes (in 2015 113,984 , in $2016-118,153$, in $2017-123,443$ and in 2018 - 126,786), therefore the upward trend is continued.

Some PCs were stored frozen. In 2019, 3.23\% of all PCs were subjected to freezing (including $2.17 \%$ of pooled PCs, $5.26 \%$ of PCs from apheresis). For the last several years, the percentage of frozen PCs has been observed to decrease; a decrease of $0.47 \%$ was also noted with regard to 2018. There was an increase in the percentage of frozen apheresis PCs (by $1.66 \%$ ), with simultaneous decrease of percentage of pooled PCs (by 1.63\%). However, in consecutive years, the percentage of frozen PCs in individual Centers is on the same level (with the exception of Wałbrzych and Racibórz) despite the recommendations for the number to be reduced. The percentage differs significantly between Centers - from $0 \%$ in Kalisz and Poznań to $17.2 \%$ in Słupsk (a decrease by $1.5 \%$ as compared to 2018 ), $19.4 \%$ in Wałbrzych (a decrease by $24.3 \%$ ), $24.7 \%$ in Opole (increase 
Table 4. Sites of whole blood collection in 2019

\begin{tabular}{|c|c|c|c|c|c|c|c|}
\hline \multirow[t]{3}{*}{ Centers } & \multicolumn{7}{|c|}{ Whole blood collected (units and percentage)* } \\
\hline & \multicolumn{2}{|c|}{ Center site } & \multicolumn{2}{|c|}{ Local collection site } & \multicolumn{2}{|c|}{ Mobile collection site } & \multirow{2}{*}{$\begin{array}{c}\text { Total } \\
\text { J. }\end{array}$} \\
\hline & J. & $\%$ & J. & $\%$ & J. & $\%$ & \\
\hline Białystok & 25466 & 40.87 & 17883 & 28.70 & 18960 & 30.43 & 62309 \\
\hline Bydgoszcz & 17090 & 24.02 & 26412 & 37.12 & 27647 & 38.86 & 71149 \\
\hline Gdańsk & 19454 & 32.00 & 32844 & 54.03 & 8495 & 13.97 & 60793 \\
\hline Kalisz & 8363 & 19.39 & 18510 & 42.91 & 16259 & 37.70 & 43132 \\
\hline Katowice & 15383 & 12.88 & 67417 & 56.46 & 36607 & 30.66 & 119407 \\
\hline Kielce & 15348 & 45.19 & 10486 & 30.88 & 8126 & 23.93 & 33960 \\
\hline Kraków & 23867 & 25.75 & 48167 & 51.96 & 20661 & 22.29 & 92695 \\
\hline Lublin & 15357 & 26.64 & 32470 & 56.33 & 9811 & 17.02 & 57638 \\
\hline Łódź & 19561 & 31.30 & 21744 & 34.79 & 21187 & 33.90 & 62492 \\
\hline Olsztyn & 12090 & 28.10 & 19120 & 44.45 & 11809 & 27.45 & 43019 \\
\hline Opole & 6642 & 22.83 & 17234 & 59.24 & 5217 & 17.93 & 29093 \\
\hline Poznań & 26596 & 27.21 & 45818 & 46.88 & 25330 & 25.91 & 97744 \\
\hline Racibórz & 4284 & 13.53 & 19583 & 61.83 & 7806 & 24.65 & 31673 \\
\hline Radom & 11629 & 47.30 & 3483 & 14.17 & 9475 & 38.54 & 24587 \\
\hline Rzeszów & 15479 & 23.87 & 43667 & 67.33 & 5713 & 8.81 & 64859 \\
\hline Słupsk & 10619 & 47.87 & 7716 & 34.79 & 3846 & 17.34 & 22181 \\
\hline Szczecin & 21288 & 42.87 & 17743 & 35.73 & 10623 & 21.39 & 49654 \\
\hline Wałbrzych & 11082 & 40.54 & 0 & 0 & 16253 & 59.46 & 27335 \\
\hline Warszawa & 27494 & 23.86 & 54940 & 47.68 & 32788 & 28.46 & 115222 \\
\hline Wrocław & 33739 & 46.24 & 27304 & 37.42 & 11916 & 16.33 & 72959 \\
\hline Ziel. Góra & 8148 & 25.42 & 16761 & 52.30 & 7140 & 22.28 & 32049 \\
\hline Total & 348979 & 28.75 & 549302 & 45.25 & 315669 & 26.00 & 1213950 \\
\hline
\end{tabular}

*incomplete donations included

by $0.4 \%$ ), $34.2 \%$ in Racibórz (decrease by $25.8 \%$ ) and $35.1 \%$ in Radom (increase by $2.9 \%$ ). As in 2018, Racibórz reported the highest percentage of frozen pooled PCs (43\%) but a decrease by $32.2 \%$ was observed. On the other hand, Radom and Slupsk, recorded the highest percentage of frozen apheresis PCs (45\% and 39\%, respectively). At the same time, a large increase in the percentage of frozen components was observed in Białystok - $12.1 \%$, over a twofold increase (from $6.63 \%$ in 2018).

In 2019, thawed PCs were $2.95 \%$ of all PC therapeutic units issued for clinical use, i.e. $0.75 \%$ less than in 2018. The largest number of thawed PC units was issued by Racibórz ( $49.0 \%$ of all PC units issued for clinical use), Radom (37, 5\%), Opole (27.5\%), Wałbrzych (20.0\%) and Slupsk (16.3\%).
The Centers in Racibórz and Wałbrzych reported a marked decrease as compared to 2018 (by $30 \%$ and $21 \%$, respectively).

\section{Fresh frozen plasma}

In 2019 , a total of $1,344,092 \mathrm{FFP}$ units were prepared (in 2018 - 1,298,216 units). As in the previous years, FFP was mainly obtained by manual method, i.e. plasma obtained from anticoagulated whole blood. With this method 1,173,572 FFP units were obtained in 2019. On the other hand, with a less frequent method of apheresis 170,520 units were obtained, i.e. $12.69 \%$ of the total (in the previous year, 143,258 units, i.e. $11.04 \%$ of the total). The percentage of FFP obtained by apheresis differed between Centers and ranged from $0.01 \%$ in Zielona Góra to $41.86 \%$ in Kalisz. 
Table 5. Units of RBCs prepared in Polish Regional Blood Transfusion Centers in 2019

\begin{tabular}{|c|c|c|}
\hline Centers & RBCs & $\begin{array}{c}\text { Increase/ } \\
\text { /decrease as } \\
\text { compared to } \\
2018\end{array}$ \\
\hline Białystok & 60522 & $\uparrow$ \\
\hline Bydgoszcz & 70734 & $\uparrow$ \\
\hline Gdańsk & 60121 & $\uparrow$ \\
\hline Kalisz & 40868 & $\uparrow$ \\
\hline Katowice & 116513 & $\uparrow$ \\
\hline Kielce & 33671 & $\uparrow$ \\
\hline Kraków & 91844 & $\uparrow$ \\
\hline Lublin & 57620 & $\uparrow$ \\
\hline Łódź & 60990 & $\uparrow$ \\
\hline Olsztyn & 42400 & $\downarrow$ \\
\hline Opole & 28941 & $\uparrow$ \\
\hline Poznań & 93321 & $\uparrow$ \\
\hline Racibórz & 30860 & $\downarrow$ \\
\hline Radom & 24051 & $\uparrow$ \\
\hline Rzeszów & 60996 & $\uparrow$ \\
\hline Słupsk & 21644 & $\downarrow$ \\
\hline Szczecin & 49358 & $\downarrow$ \\
\hline Wałbrzych & 27028 & $\uparrow$ \\
\hline Warszawa & 113639 & $\uparrow$ \\
\hline Wrocław & 63647 & $\downarrow$ \\
\hline Zielona Góra & 31565 & $\downarrow$ \\
\hline Razem & 1180333 & $\uparrow$ \\
\hline
\end{tabular}

$\downarrow$ - decrease as compared to 2018; $\uparrow$ — increase as compared to 2018

Table 9 presents the number of FFP units obtained by the manual method and by apheresis in individual Centers in 2019.

A total of 259,189 units of FFP (19.28\% of the collected plasma) were issued for clinical use which is slightly less than in 2018 (271,702 units of FFP, i.e. 20.93\%). In individual Centers, the percentage of FFP issued for clinical purposes ranged from $5.53 \%$ in Kalisz to $33.30 \%$ in Warsaw (Table 10).

\section{Granulocyte concentrate}

As in previous years, in 2019, granulocyte concentrate $(\mathrm{GC})$ was sporadically obtained (94 donations), i.e. less frequently than in 2018 (116 donations). The number of Centers collecting GC also decreased (in 2018 - 6, in 2019 - 5 Centers). Most GC donations took place in Bydgoszcz (39) and Kraków (21).
Table 6. Leukocyte-depleted and irradiated RBCs prepared in Polish Centers in 2019

\begin{tabular}{lccc}
\hline Centers & $\begin{array}{c}\text { Units of } \\
\text { leukocyte- } \\
\text {-depleted } \\
\text { RBCs }\end{array}$ & $\begin{array}{c}\text { Units } \\
\text { of irra- } \\
\text { diated } \\
\text { RBCs }\end{array}$ & $\begin{array}{c}\text { Units of both } \\
\text { irradiated and } \\
\text { leukocyte- } \\
\text {-depleted RBCs }\end{array}$ \\
\hline Białystok & 2198 & 0 & 6152 \\
Bydgoszcz & 2995 & 0 & 10153 \\
Gdańsk & 1529 & 3 & 14598 \\
Kalisz & 11545 & 0 & 0 \\
Katowice & 34889 & 0 & 7043 \\
Kielce & 6282 & 0 & 3341 \\
Kraków & 7109 & 451 & 6967 \\
Lublin & 834 & 0 & 8685 \\
tódź & 9819 & 31 & 10568 \\
Olsztyn & 4970 & 0 & 4194 \\
Opole & 3776 & 0 & 499 \\
Poznań & 15595 & 4 & 7913 \\
Racibórz & 3570 & 0 & 25 \\
Radom & 1943 & 0 & 106 \\
Rzeszów & 429 & 77 & 7029 \\
Słupsk & 1787 & 0 & 1550 \\
Szczecin & 436 & 119 & 2174 \\
Wałbrzych & 325 & 0 & 0 \\
Warszawa & 102136 & 0 & 6399 \\
Wrocław & 4653 & 44 & 8738 \\
Zielona & 4044 & 0 & 2044 \\
Góra & 220864 & 729 & 108178 \\
Total & & & \\
\hline & & 0 & 0 \\
\hline
\end{tabular}

\section{Quarantine and inactivation of biological pathogens in labile blood components}

In Poland, we rely solely on quarantine ${ }^{1}$ or pathogen inactivated FFP and cryoprecipitate in order to ensure the safety of transfused blood components. In vitro studies as well as multicenter clinical trials have also proved that some methods of inactivation (Mirasol PRT with riboflavin, Intercept with amotosalen hydrochloride) not only minimize the risk of pathogen transmission but may also serve as an alternative to irradiation of cellular blood components for prevention of post-transfusion Graft Versus Host Disease (TA-GvHD) [2-4].

In 2019, 13 Centers used pathogen inactivation technology (PRT) for inactivation of biological pathogens in plasma. The following systems were used :

${ }^{1}$ Quarantine of FFP and cryoprecipitate consists in storage for at least 16 weeks of donation date followed by testing the donor for infectious disease markers (to eliminate the diagnostic window period). 
Table 7. PCs from whole blood and apheresis (2019)

\begin{tabular}{|c|c|c|c|c|}
\hline \multirow[t]{2}{*}{ Centers } & \multicolumn{4}{|c|}{ PC (therapeutic doses) } \\
\hline & Pooled from whole blood & Apheresis & Total & $\%$ apheresis KKP \\
\hline Białystok & 1017 & 3690 & 4707 & 78.39 \\
\hline Bydgoszcz & 8287 & 1225 & 9512 & 12.88 \\
\hline Gdańsk & 5530 & 741 & 6271 & 11.82 \\
\hline Kalisz & 1965 & 801 & 2766 & 28.96 \\
\hline Katowice & 9392 & 6899 & 16291 & 42.35 \\
\hline Kielce & 3532 & 1027 & 4559 & 22.53 \\
\hline Kraków & 7221 & 2921 & 10142 & 28.80 \\
\hline Lublin & 4083 & 1688 & 5771 & 29.25 \\
\hline Łódź & 4825 & 875 & 5700 & 15.35 \\
\hline Olsztyn & 3441 & 730 & 4171 & 17.51 \\
\hline Opole & 690 & 602 & 1292 & 46.59 \\
\hline Poznań & 10021 & 3145 & 13166 & 23.89 \\
\hline Racibórz & 848 & 477 & 1325 & 36.00 \\
\hline Radom & 592 & 859 & 1451 & 59.20 \\
\hline Rzeszów & 5515 & 1491 & 7006 & 21.28 \\
\hline Słupsk & 1259 & 330 & 1589 & 20.76 \\
\hline Szczecin & 2095 & 2904 & 4999 & 58.09 \\
\hline Wałbrzych & 1430 & 138 & 1568 & 8.80 \\
\hline Warszawa & 4196 & 12604 & 16800 & 75.02 \\
\hline Wrocław & 3417 & 10218 & 13635 & 74.94 \\
\hline Zielona Góra & 2549 & 14 & 2563 & 0.55 \\
\hline Total & 81905 & 53379 & 135284 & 39.46 \\
\hline
\end{tabular}

- Mirasol (8 Centers);

- Theraflex MB Plasma (5 Centers);

- Intercept ( Center in Warsaw). The percentage of plasma subjected to inactivation ranged from $0.04 \%$ (Center in Kielce) to $8.71 \%$ (Center in Warsaw). Countrywide, a total of $2.8 \%$ of all plasma was subjected to inactivation. In addition, subjected to inactivation was plasma dedicated for clinical use outside the territory of the Republic of Poland $(2.14 \%)$. A total of $87.93 \%$ of quarantine FFP and $87.66 \%$ of quarantine cryoprecipitate were issued for clinical use as well as $11.97 \%$ of pathogen inactivated FFP and $12.34 \%$ of pathogen inactivated cryoprecipitate (cryoprecipitate in Poznań only).

In 5 Centers, inactivation of pooled PCs was implemented (all 5 used the Mirasol system; the Center in Warsaw also used the Intercept system). The percentage of pooled PCs subjected to inactivation ranged from $0.03 \%$ (Center in Wrocław) to $94.30 \%$ (Center in Warsaw). Country-wide, this accounted for $4.99 \%$ of all pooled PC units.
9 Centers pathogen inactivated leukocyte depleted PCs from apheresis ( 8 Centers used Mirasol; the Center in Warsaw also used the Intercept system). The percentage of pathogen inactivated leukocyte depleted PCs from apheresis ranged from $0.14 \%$ (Center in Białystok) to $38.18 \%$ (Center in Radom) and $85.55 \%$ (Center in Warsaw). Country-wide this accounted for $21.73 \%$ of all leukocyte depleted apheresis PCs.

In 2019, a total of $11.87 \%$ of inactivated PC therapeutic units were issued for clinical use (in $2018-11.74 \%)$.

Table 11 presents the 2019-percentage of FFP units, cryoprecipitate and PC therapeutic units issued for clinical use following pathogen inactivation.

\section{Wastage of blood and blood components}

In 2019, a total of 103,487 units of blood and most common blood components were wasted, 
Table 8. Leukocyte-depleted and irradiated PCs (therapeutic doses) prepared in Polish Regional Blood Transfusion Centers (2019)

\begin{tabular}{|c|c|c|c|c|}
\hline Centers & $\begin{array}{l}\text { PC therapeutic } \\
\text { doses }\end{array}$ & $\begin{array}{l}\text { Leukocyte-depleted } \\
\text { PCs }\end{array}$ & Irradiated PCs & $\begin{array}{c}\text { Both irradiated } \\
\text { and leukocyte-depleted PCs }\end{array}$ \\
\hline Białystok & 4707 & 2 & 0 & 4703 \\
\hline Bydgoszcz & 9512 & 329 & 0 & 9183 \\
\hline Gdańsk & 6271 & 472 & 0 & 5058 \\
\hline Kalisz & 2766 & 2766 & 0 & 0 \\
\hline Katowice & 16291 & 10540 & 0 & 5751 \\
\hline Kielce & 4559 & 1000 & 0 & 2258 \\
\hline Kraków & 10142 & 4952 & 0 & 5190 \\
\hline Lublin & 5771 & 179 & 0 & 5537 \\
\hline Łódź & 5700 & 1119 & 0 & 4581 \\
\hline Olsztyn & 4171 & 511 & 0 & 3600 \\
\hline Opole & 1292 & 1245 & 0 & 47 \\
\hline Poznań & 13166 & 3948 & 53 & 8701 \\
\hline Racibórz & 1325 & 1313 & 0 & 12 \\
\hline Radom & 1451 & 1398 & 0 & 18 \\
\hline Rzeszów & 7006 & 3548 & 0 & 3458 \\
\hline Słupsk & 1589 & 744 & 0 & 845 \\
\hline Szczecin & 4999 & 2587 & 0 & 2412 \\
\hline Wałbrzych & 1568 & 1568 & 0 & 0 \\
\hline Warszawa & 16800 & 16785 & 0 & 15 \\
\hline Wrocław & 13635 & 2064 & 0 & 11538 \\
\hline Zielona Góra & 2563 & 1563 & 0 & 998 \\
\hline Total & 135284 & 58633 & 53 & 73905 \\
\hline
\end{tabular}

including 14,013 units of anticoagulated whole blood, 32,798 units of RBCs, 49,285 units of FFP, 1,279 therapeutic units of apheresis PC, 4,778 PCs from whole blood, as well as 1334 units of cryoprecipitate.

As in the previous year, the most common reasons for wastage of blood components were:

- date expiry;

- seropositivity for transfusion transmitted diseases, syphilis, implementation of look-back procedure;

- Other causes, including:

- inadequate visual control;

- low quantity/volume;

- seropositive serological results;

- other, including incorrect procedures, medical deferral, mechanical damage, donor self-deferral.

Subjected to wastage were also blood components from autologous donations that were not put to clinical use.
Table 12 presents the number of blood components wasted in individual Centers in 2019; causes of wastage are shown in Table 13.

\section{Discussion}

In light of the available data, the worldwide number of transfused blood components is still too high despite recommendations to limit their use (particularly with regard to $\mathrm{RBCs}$ ), intensive appeals for rational blood therapy as well as the recent reports of spectacular successes in countries which implemented patient blood management programs (PBM) [5]. The demand for blood and blood components is therefore still high and some countries report a growing demand for certain blood components. This is brought about by advancement in various fields of medicine as well as other factors such as the aging of societies. 
Table 9. FFP units (from whole blood and apheresis) prepared in Polish regional Blood Transfusion Centers v(2019). Number of units

\begin{tabular}{|c|c|c|c|c|}
\hline Centers & $\begin{array}{l}\text { Whole blood } \\
\text { (manual method) }\end{array}$ & Apheresis & Total & $\%$ apheresis FFP \\
\hline Białystok & 60522 & 24944 & 85466 & 29.19 \\
\hline Bydgoszcz & 70360 & 16566 & 86926 & 19.06 \\
\hline Gdańsk & 60053 & 4167 & 64220 & 6.49 \\
\hline Kalisz & 40868 & 29423 & 70291 & 41.86 \\
\hline Katowice & 116512 & 4777 & 121289 & 3.94 \\
\hline Kielce & 33635 & 2278 & 35913 & 6.34 \\
\hline Kraków & 91868 & 117 & 91985 & 0.13 \\
\hline Lublin & 55092 & 13006 & 68098 & 19.10 \\
\hline Łódź & 60990 & 261 & 61251 & 0.43 \\
\hline Olsztyn & 40187 & 5019 & 45206 & 11.10 \\
\hline Opole & 28941 & 113 & 29054 & 0.39 \\
\hline Poznań & 93255 & 9274 & 102529 & 9.04 \\
\hline Racibórz & 30860 & 6202 & 37062 & 16.73 \\
\hline Radom & 24038 & 5006 & 29044 & 17.24 \\
\hline Rzeszów & 60996 & 6782 & 67778 & 10.01 \\
\hline Słupsk & 21631 & 2452 & 24083 & 10.18 \\
\hline Szczecin & 49358 & 6537 & 55895 & 11.70 \\
\hline Wałbrzych & 25598 & 103 & 25701 & 0.40 \\
\hline Warszawa & 113639 & 10164 & 123803 & 8.21 \\
\hline Wrocław & 63604 & 23329 & 86933 & 26.84 \\
\hline Zielona Góra & 31565 & 3 & 31568 & 0.01 \\
\hline Total & 1173572 & 170520 & 1344092 & 12.69 \\
\hline
\end{tabular}

Therefore, the basic factor that determines the availability of blood supply is still the good will, and thus - a sufficient number of volunteer, nonremunerated blood donors [6-10].

In line with the observations presented above, the number of donors in the Centers in Poland was slightly higher in 2019 than in 2018 (590 893 and 590470 respectively), which may be the sign of the end of the downward trend observed for the previous years.

An unfavorable phenomenon observed in the recent years is a decrease of population in the 18-65 age group - the potential "recruitment source" of blood donors. According to the data provided in the Demographic Yearbook reports (Central Statistical Office of Poland) for December 312011 , this number was estimated at $26,460,477$, while for December 31, 2019 - only 25,009,048 $[11,12]$. During this period (2011-2019), the popu- lation in the aforementioned age group decreased by almost one and a half million, which may impact negatively on the number of active blood donors.

In member states of the Council of Europe, the average number of blood donors per 1,000 inhabitants decreased from 29.0 in 2008-to 25.0 in 2011 [13]. In Poland, the numbers per 1000 inhabitants were 15.39 in 2019 (in 2018 - 15.37, and in 2017 - 15.30).

Moreover, both in Poland and other countries, there is a downward trend in the number of people reporting their willingness to donate blood; this is especially true for certain age groups. In Poland, such tendency is observed especially in the 18-24 age group - a group of potential donors of blood and blood components in the future [14].

Apart from the above-mentioned demographic changes, the number of blood donors is adversely affected by factors such as: 
Table 10. FFP units issued for clinical use in Polish Regional Blood Transfusion Centers (2019)

\begin{tabular}{|c|c|c|c|}
\hline Centers & $\begin{array}{l}\text { Prepared } \\
\text { (units) }\end{array}$ & $\begin{array}{l}\text { Issued for } \\
\text { clinical } \\
\text { use (units) }\end{array}$ & $\begin{array}{l}\text { \% FFP re- } \\
\text { leased } \\
\text { for clinical } \\
\text { use }\end{array}$ \\
\hline Białystok & 85466 & 12423 & 14.54 \\
\hline Bydgoszcz & 86926 & 16395 & 18.86 \\
\hline Gdańsk & 64220 & 9514 & 14.81 \\
\hline Kalisz & 70291 & 3885 & 5.53 \\
\hline Katowice & 121289 & 25431 & 20.97 \\
\hline Kielce & 35913 & 7272 & 20.25 \\
\hline Kraków & 91985 & 21928 & 23.84 \\
\hline Lublin & 68098 & 15214 & 22.34 \\
\hline Łódź & 61251 & 17109 & 27.93 \\
\hline Olsztyn & 45206 & 8333 & 18.43 \\
\hline Opole & 29054 & 4426 & 15.23 \\
\hline Poznań & 102529 & 18210 & 17.76 \\
\hline Racibórz & 37062 & 2698 & 7.28 \\
\hline Radom & 29044 & 2807 & 9.66 \\
\hline Rzeszów & 67778 & 11864 & 17.50 \\
\hline Słupsk & 24083 & 3047 & 12.65 \\
\hline Szczecin & 55895 & 13761 & 24.62 \\
\hline Wałbrzych & 25701 & 5345 & 20.80 \\
\hline Warszawa & 123803 & 41221 & 33.30 \\
\hline Wrocław & 86933 & 12367 & 14.23 \\
\hline $\begin{array}{l}\text { Zielona } \\
\text { Góra }\end{array}$ & 31568 & 5939 & 18.81 \\
\hline Total & 1344092 & 259189 & 18.06 \\
\hline
\end{tabular}

- periodic disease outbreaks;

- travel-associated risk of infections e.g. malaria or West Nile virus [15, 16];

- emerging infectious diseases, e.g. the Zika virus epidemic [17-19];

- health condition of the population, including reduced hemoglobin levels (the most common cause of deferrals in the last several years) [20-22];

- no opportunity to donate blood or economic reasons.

The number of autologous donors has been low in recent years. In 2019, it was estimated at 556 which is slightly higher than in 2018 (500), but lower than in 2017 (561). The smaller number of preoperative autologous donations is a phenomenon observed in many countries [23]. In line with current recommendations, autologous donations
Table 11. Pathogen inactivated FFP (\%), cryoprecipitate $(\%)$ and PCs (\%) issued for clinical use (2019)

\begin{tabular}{lccc}
\hline Centers & $\begin{array}{c}\text { \% FFP } \\
\text { (units) }\end{array}$ & $\begin{array}{c}\text { \% Cryopreci- } \\
\text { pitate (units) }\end{array}$ & $\begin{array}{c}\text { \% KKP } \\
\text { (packages) }\end{array}$ \\
\hline Białystok & 3.63 & 0 & 0.11 \\
Bydgoszcz & 4.08 & 0 & 0 \\
Gdańsk & 2.01 & 0 & 0 \\
Kalisz & 0 & 0 & 0 \\
Katowice & 5.87 & 0 & 0.46 \\
Kielce & 0 & 0 & 4.06 \\
Kraków & 17.80 & 0 & 0.34 \\
Lublin & 0.48 & 0 & 0.50 \\
Lódź & 13.22 & 0 & 2.65 \\
Olsztyn & 0 & 0 & 0 \\
Opole & 0 & 0 & 0 \\
Poznań & 34.93 & 100 & 0 \\
Racibórz & 16.90 & 0 & 0 \\
Radom & 0 & 0 & 24.92 \\
Rzeszów & 11.78 & 0 & 0 \\
Słupsk & 0 & 0 & 0 \\
Szczecin & 0 & 0 & 0 \\
Wałbrzych & 0 & 0 & 1.10 \\
Warszawa & 26.53 & 0 & 0 \\
Wrocław & 22.89 & 0 & 0 \\
Zielona & 0 & 0 & 0.87 \\
Góra & & 12.34 & 0 \\
Total & 11.97 & & 0 \\
\hline & & 0 & 0 \\
\hline
\end{tabular}

are mostly relied on when they have significant advantage over allogenic transfusions and when the indications for transfusion are strong. Autologous donations are useful primarily in cases when compatible allogeneic blood is unavailable, e.g. when the patient has antibodies against antigens with high prevalence in population [24].

In 2019 , the total number of blood and blood component donations amounted to $1,291,392$, including 1,220,079 whole blood donations,; once again there was a slight increase as compared to the previous year (in 2018, 1,264,903 and 1,184,311 respectively).

One of the methods used for more effective collection of blood components is automated apheresis. In 2019, the number of apheresis PC donations and plasma donations combined increased as compared to 2018 (from 19,143 to 28,966). Likewise for plasma donations (from 36,655 to 42,386 ). On the other hand, the number of PC donations decreased (from 24,585 to 17 736). Collection by 
Table 12. Wastage of blood components in Polish Regional Blood Transfusion Center (2019)

\begin{tabular}{|c|c|c|c|c|c|c|}
\hline & \multirow[t]{2}{*}{ Whole blood } & \multirow[t]{2}{*}{ RBCs } & \multicolumn{2}{|c|}{ PC therapeutic units } & \multirow[t]{2}{*}{ FFP } & \multirow{2}{*}{$\begin{array}{c}\text { Cryoprecipi } \\
\text { tate }\end{array}$} \\
\hline & & & $\begin{array}{l}\text { Pooled (from } \\
\text { whole blood) }\end{array}$ & Apheresis & & \\
\hline Białystok & 261 & 623 & 14 & 9 & 1008 & 84 \\
\hline Bydgoszcz & 392 & 694 & 255 & 0 & 3176 & 134 \\
\hline Gdańsk & 580 & 1501 & 0 & 9 & 2277 & 147 \\
\hline Kalisz & 167 & 1478 & 172 & 16 & 961 & 64 \\
\hline Katowice & 1588 & 3421 & 431 & 263 & 2531 & 20 \\
\hline Kielcach & 0 & 1012 & 574 & 32 & 1660 & 47 \\
\hline Kraków & 555 & 1491 & 180 & 49 & 7194 & 83 \\
\hline Lublin & 82 & 1477 & 207 & 125 & 1499 & 16 \\
\hline Łódź & 1313 & 2252 & 313 & 44 & 3431 & 85 \\
\hline Olsztyn & 157 & 1610 & 213 & 46 & 1295 & 189 \\
\hline Opole & 152 & 521 & 26 & 32 & 995 & 0 \\
\hline Poznań & 1431 & 3909 & 665 & 150 & 3771 & 19 \\
\hline Racibórz & 114 & 770 & 82 & 20 & 681 & 2 \\
\hline Radom & 433 & 1692 & 139 & 60 & 1305 & 62 \\
\hline Rzeszów & 3394 & 1444 & 593 & 60 & 1902 & 60 \\
\hline Słupsk & 0 & 706 & 104 & 19 & 565 & 10 \\
\hline Szczecin & 180 & 1567 & 107 & 119 & 2860 & 92 \\
\hline Wałbrzych & 324 & 920 & 107 & 14 & 334 & 0 \\
\hline Warszawa & 1546 & 2859 & 177 & 0 & 8605 & 142 \\
\hline Wrocław & 859 & 2081 & 119 & 208 & 2489 & 78 \\
\hline Zielona Góra & 485 & 770 & 300 & 4 & 746 & 0 \\
\hline Total & 14013 & 32798 & 4778 & 1279 & 49285 & 1334 \\
\hline
\end{tabular}

Table 13. Reasons for blood component wastage in Polish Regional Blood Transfusion Centers (2019)

\begin{tabular}{|c|c|c|c|c|c|c|}
\hline Reason & $\begin{array}{l}\text { Whole } \\
\text { blood }\end{array}$ & RBCs & $\begin{array}{l}\text { PC therapeu- } \\
\text { tic doses } \\
\text { pooled from } \\
\text { whole blood }\end{array}$ & $\begin{array}{l}\text { PC the- } \\
\text { rapeutic } \\
\text { doses } \\
\text { Apheresis }\end{array}$ & FFP & $\begin{array}{l}\text { Cryopre- } \\
\text { cipitate }\end{array}$ \\
\hline Expiry date & 1 & 12175 & 3081,65 & 502,2 & 1095,3 & 27 \\
\hline $\begin{array}{l}\text { Seropositive for transfusion transmitted dise- } \\
\text { ases, syphilis, implementation of look-back } \\
\text { procedure }\end{array}$ & 36.4 & 2408 & 200 & 117 & 3482 & 1 \\
\hline $\begin{array}{l}\text { Other causes, including: } \\
\text { - inadequate visual control, } \\
\text { - low quantity/volume, } \\
\text { - seropositive serological results, other, inclu- } \\
\text { ding incorrect procedures, medical deferral, } \\
\text { mechanical damage, donor self-deferral. }\end{array}$ & 13976 & 18023 & 1496 & 660 & 44243 & 1306 \\
\hline $\begin{array}{l}\text { Unused blood components from autologous } \\
\text { donations }\end{array}$ & 0 & 192 & 0 & 0 & 482 & 0 \\
\hline Total & 14013 & 32798 & 4778 & 1279 & 49302 & 1334 \\
\hline
\end{tabular}


apheresis of other blood components, i.e. RBCs and granulocyte concentrate (GC) was sporadic.

It should be noted that automated methods (apheresis) are still used in Poland to a relatively small extent - in 2019 - only $6.92 \%$ of all donations (in $2018-6.37 \%$ ).

Mobile collections are organized to make blood donation easier for donors. In 2019 the Centers organized 13,048 teams, which is less than in the previous year (13,189 teams). For the last several years, the percentage of whole blood donations during mobile collections has been approximately $26-29 \%$ (in $2019-26 \%$ ). In 2019, as in the previous years, blood was mostly collected at local collection sites $(45.25 \%)$ which may be explained by the fact that donors are more willing to donate in familiar places. However, the contemporary high standards for collection of blood dedicated for clinical use do not favor small collection sites; centralization of blood transfusion service is recommended.

The demand for blood components is influenced by a number of factors including: current guidelines issued by scientific societies, profile of the clinical ward and recommendations of the physician. Economic factors are also important.

In 2019, about 30.7 units of RBC per 1,000 inhabitants were issued for clinical purposes (in 2018 30.38 units, in $2017-30.22$ units, in $2016-29.99$, in $2015-29.87$ units) [12, 25-28]. In recent years therefore, a slight upward trend can be observed. However, the RBC consumption in Poland is still evidently lower than in some other European countries - for example, in 2011 the RBC consumption in 32 member states of the Council of Europe was on average 37 units/1,000 inhabitants [13].

In 2019 the number of FFP units issued for clinical purposes amounted to 259,189 and was lower than in the previous year (in $2018-271,702$ ). The ratio of $\mathrm{RBC}$ for clinical use to FFP was approximately 4,4 (in $2018-4.09$, in $2017-3.77$, in $2016-3.56$, in $2015-3.45$ ); so the upward trend continues. The data indicate that the consumption of FFP gradually decreases as compared to RBC. However, the RBC/FFP ratio is still higher than in many other European countries [13]. This may be explained by the lower consumption of $\mathrm{RBC}$ in Poland - as mentioned above, but in many cases also by the fact that FFP is used with no sufficient reason and sometimes against current restricted indications [29, 30].

As mentioned above, the last several years have witnessed the increase in consumption of PC. In the period 2015-2019 the number of PC therapeutic units issued for clinical use increased from 113,984 to 129,301 (by over 13\%). A similar phenomenon was observed in other countries [31].

Additional preparation methods (leukocyte depletion, irradiation) for prevention of transfusion associated adverse reactions were applied much more frequently to PCs $(43.34 \%$ leukocyte depleted PCs, $54.63 \%$ irradiated leukocyte depleted PCs and $0.04 \%$ irradiated PCs) than to RBCs (18.71\% leukocyte depleted, $9.17 \%$ irradiated and $0.06 \%$ leukocyte depleted and irradiated). Leukocyte-depleted $\mathrm{RBC}$ s require additional preparation, while in the case of $\mathrm{PC}$ s from apheresis leukodepletion may occur at collection. Some automated methods of PC preparation from buffy coat also allow for the simultaneous elimination of leukocytes but the cost is still relatively high as compared to manual methods. Automated methods do however guarantee high quality parameters due to the standardization.

Most Centers currently prepare almost exclusively leukocyte-depleted PCs (Table 8). As mentioned above, in 2019 leukocyte-depleted PCs (including leukocyte-depleted and leukocyte-depleted irradiated PCs) accounted for approximately 97.97\% of all PCs obtained country-wide. Regular/ /common leuko-depletion is now implemented in many countries, although its effectiveness in preventing transfusion-related adverse reactions is sometimes questioned [32].

As in the previous years, the number of frozen PCs in some Centers is too high. As mentioned above, in 2019 a further decrease in the percentage of frozen PCs was observed (in 2017 by $0.9 \%$, in 2018 by $0.47 \%$ ). The percentage reported for the whole country is acceptable. It must be noted however that routine freezing of large volumes of blood components - eg. Racibórz (43.0\% pooled and $18.2 \%$ apheresis PCs), Radom (20.6\% pooled and $45.7 \%$ apheresis PCs), Opole (24.2\% pooled and $25.2 \%$ apheresis PCs) or Slupsk (39.8\% apheresis PCs) - is not to be accepted. Thawed PCs may be used only in exceptional cases, therefore it is not recommended to freeze more than $10 \%$ of all PCs prepared. This does not refer to freezing of apheresis PCs collected from patients with anti-HLA or anti-HPA antibodies.

It should be emphasized that freezing and thawing negatively affect the quality parameters of platelets and their therapeutic efficacy. According to 2019 data, the situation has improved especially in Centers of Racibórz and Wałbrzych which decreased the amounts of frozen PCs issued for clinical use by $30 \%$ and $21 \%$ respectively as compared to 2018 . 
Depletion of blood and blood component supplies is also associated with wastage which - though sometimes inevitable - occurs for a number of reasons. Most probably, some of the wastage could be avoided by better adherence to procedures. In order to limit the extent of waste of blood and blood components some countries have implemented special procedures [33].

The most common causes of wastage in 2019 (like in the previous years) belonged to the category of "other reasons", in particular:

- inadequate visual control;

— incorrect/low volume;

- seropositive test results;

- incorrect procedures, medical deferral, mechanical damage, donor self-deferral, etc.

Expiry date or positive results of viral tests were less frequently the cause of waste. Subjected to waste were also unused blood components from autologous donations.

Data related to quarantine and pathogen inactivated FFP and cryoprecipitate reveal that quarantine FFP is still most commonly used in clinical practice. As in the previous years, most Centers did not make adequate use of the illuminators installed on their premises. The most likely reason is that physicians rarely order pathogen inactivated FFP and PCs. One reason for limited use of pathogen inactivated plasma is the easy access to quarantine FFP. On the other hand, physicians who order components for clinical wards are not always fully aware that pathogen inactivated plasma is much safer than quarantine plasma; it offers protection against the consequences of the "diagnostic window" (just like quarantine plasma) but also prevents the transmission of a wide spectrum of pathogens.

Study results demonstrated that both the Mirasol and Intercept PRT systems reduce the number of viable T cells in PCs (by $>6$ logs and $>5.4 \mathrm{log}$ respectively) [4]. Further research confirmed these systems to be an alternative to irradiation of cellular blood components used so far for prevention of TA-GvHD in high-risk patients [2].

Physicians sometimes order PCs subjected to pathogen inactivation (using one of the above mentioned systems) and irradiated. This procedure is incorrect, because the use of both gamma irradiation and inactivation may induce platelet activation which contributes to faster removal of platelets from the recipient's circulatory system [34].

\section{Conclusions}

The study is a brief presentation of selected issues related to the activities of the Polish Re- gional Blood Transfusion Centers (Centers) in 2019 , as well as to some recently observed trends of changes which may serve as good starting point for the analysis of issues related to the activities of healthcare units in Polish blood transfusion service, for comparison of experiences and development of optimal solutions for the future. Similar data reviews related to blood and blood components are systematically performed in other countries.

\section{Current problems of blood transfusion medicine}

Initiatives related to rationalization and optimization of the use of blood and blood components have been reported for a number of years. Since 2005, when the patient blood management (PBM) program was first announced, efforts have been focused on proper understanding of the issue as well as on implementation of appropriate solutions into everyday clinical practice. The purpose of these initiatives and measures is to limit the use of allogeneic blood components in favor of the rational use of the patient's own blood.

Implementation of the PBM principles is also extremely significant from the point of view of securing sufficient numbers of donors. As mentioned earlier, one of the pressing problems of contemporary transfusion medicine is the aging of societies and the decrease in the number of people eligible for blood donation as well as the downward trend - observed also in Poland - for willingness to donate blood in certain age groups.

As already signaled in earlier publications, the PBM program gained full support from numerous organizations including the World Health Organization and the European Commission as well as research and expert societies [35-38]. It is necessary however to continue activities aimed at wider application of PBM principles in everyday clinical practice. There is no doubt as to the principle of implementation of the PBM program but the methods of effective implementation at hospital level remain an open question. The EU institutions devote much attention to analyses of blood consumption and implementation of PBM programs. Also Poland has launched initiatives directed at implementation of PBM principles. Among others, attention is focused on application and use of PBM principles in the activities of hospital transfusion committees [39].

In some countries the PBM approach has already been adopted and has brought about visible benefits. In the United States for example, 
assessment of blood components consumption in recent years has demonstrated significant decrease in the number of transfused RBC and plasma units as well as PCs - though to a lesser extent [8]. Although slightly changed since 2015, the tendency to further reduce the consumption of blood components is expected to continue in the future [40]. Authors point out that one of the reasons for this phenomenon - apart from implementation of PBM principles - is the growing cost of blood component preparation as well as the decreasing number of donors [41].

The need to rationalize blood therapy is also affected by the risk of transfusion-related adverse reactions [42]. Attention should be focused on the significance of $\mathrm{RBC}$ storage time prior to transfusion and the impact on the biochemical and morphological changes occurring in red blood cells (“storage lesion") [43]. Further work on RBC preparation and storage may contribute to the improvement of therapy outcome and cost-effectiveness.

One of the most important documents on the principles of PBM are the evidence-based recommendations for PBM presented during the Consensus Conference in Frankfurt in 2018 organized by the largest global and European organizations [44]. Recently, these recommendations were discussed during the $36^{\text {th }}$ International ISBT Congress ( on-line) of 12-16 December 2020 [45].

\section{Acknowledgements}

The Authors express their thanks to the National Blood Center and the Regional Blood Transfusion Centers for access to the relevant information and for support in the analysis of forwarded data.

\section{References}

1. Ustawa $z$ dnia 22 sierpnia $1997 \mathrm{r}$ o publicznej służbie krwi (Dz. U. Nr 106, poz. 681 z późn. zmian.).

2. Osselaer JC, Cazenave JP, Lambermont M, et al. An active haemovigilance programme characterizing the safety profile of 7437 platelet transfusions prepared with amotosalen photochemical treatment. Vox Sang. 2008; 94(4): 315-323, doi: 10.1111/j.1423-0410.2007.01035.x, indexed in Pubmed: 18248574.

3. Schlenke P. Pathogen inactivation technologies for cellular blood components: an update. Transfus Med Hemother. 2014; 41(4): 309-325, doi: 10.1159/000365646, indexed in Pubmed: 25254027.

4. Grass JA, Wafa T, Reames A, et al. Prevention of transfusion-associated graft-versus-host disease by photochemical treatment. Blood. 1999; 93(9): 3140-3147, indexed in Pubmed: 10216113.

5. Zeller MP, Kaufman RM. Safeguarding the Patient's Own Blood Supply. JAMA. 2019; 321(10): 943-945, doi: 10.1001/ jama.2019.0553, indexed in Pubmed: 30860548.
6. Farmer S, Trentino K, Hofmann A, et al. A Programmatic Approach to Patient Blood Management - ReducingTransfusions and Improving Patient Outcomes. Open Anesthesiol J. 2015; 9(1): 6-16, doi: 10.2174/1874321801509010006.

7. van Ho, Koopman MMW, Koffijberg $\mathrm{H}$, et al. Historical time trends in red blood cell usage in the Netherland. Int J Clin Transfus Med. 2016; 4: 67-77, doi: https://doi.org/10.2147/IJCTM. S103644.

8. Ellingson KD, Sapiano MRP, Haass KA, et al. Continued decline in blood collection and transfusion in the United States-2015. Transfusion. 2017; 57 Suppl 2: 1588-1598, doi: 10.1111/trf.14165, indexed in Pubmed: 28591469.

9. WHO Expert Group. Expert Consensus Statement on achieving self-sufficiency in safe blood and blood products, based on voluntary non-remunerated blood donation (VNRBD). Vox Sang. 2012; 103(4): 337-342, doi: 10.1111/j.1423-0410.2012.01630.x, indexed in Pubmed: 22690746.

10. World Health Organization. Towards Self-Sufficiency in Safe Blood and Blood Products based on Voluntary Non-Remunerated Donation. Global Status 2013.

11. Główny Urząd Statystyczny, Komitet Redakcyjny. Rocznik demograficzny 2012.

12. Główny Urząd Statystyczny. Ludność. Stan i struktura ludności oraz ruch naturalny $\mathrm{w}$ przekroju terytorialnym (stan $\mathrm{w}$ dniu 31.12.2019). https://stat.gov.pl/obszary-tematyczne/ludnosc/ ludnosc/ludnosc-stan-i-struktura-ludnosci-oraz-ruch-naturalny-w-przekroju-terytorialnym-stan-w-dniu-31-12-2019,6,27.html\# [online].

13. Pogłód R, Rosiek A, Grabarczyk P, et al. Charakterystyka podstawowych wskaźników dotyczących krwiodawstwa i krwiolecznictwa w Europie - aktualne wyzwania i działania. J Transf Med. 2015; 8(2): 60-77.

14. Mikołowska A, Antoniewicz-Papis J. Retrospektywna analiza wybranych aspektów działalności publicznej służby krwi jako punkt wyjścia do oceny stanu polskiego krwiodawstwa. Część 1: Charakterystyka struktury demograficznej zbiorowości dawców. Journal of Transfusion Medicine. 2020; 13(1): 29-66.

15. Rabel PO, Planitzer CB, Farcet MR, et al. Increasing West Nile virus antibody titres in central European plasma donors from 2006 to 2010. Euro Surveill. 2011; 16(10), doi: 10.2807/ ese.16.10.19812-en, indexed in Pubmed: 21435324.

16. Napp S, Petrić D, Busquets N. West Nile virus and other mosquito-borne viruses present in Eastern Europe. Pathog Glob Health. 2018; 112(5): 233-248, doi: 10.1080/20477724.2018.1483567, indexed in Pubmed: 29979950.

17. Stramer SL, Hollinger FB, Katz LM, et al. Emerging infectious disease agents and their potential threat to transfusion safety. Transfusion. 2009; 49 Suppl 2: 1S-29S, doi: 10.1111/j.1537-2995.2009.02279.x, indexed in Pubmed: 19686562.

18. Musso D, Nilles EJ, Cao-Lormeau VM. Rapid spread of emerging Zika virus in the Pacific area. Clin Microbiol Infect. 2014; 20(10): O595-O596, doi: 10.1111/1469-0691.12707, indexed in Pubmed: 24909208.

19. Jimenez A, Shaz BH, Bloch EM. Zika Virus and the Blood Supply: What Do We Know? Transfus Med Rev. 2017; 31(1): 1-10, doi: 10.1016/j.tmrv.2016.08.001, indexed in Pubmed: 27569055.

20. Rosiek A, Tomaszewska A, Lachert E, et al. Obniżone stężenie hemoglobiny najczęstszą przyczyną dyskwalifikacji krwiodaw- 
ców na terenie polski. Acta Haematologica Polonica. 2015; 46: 24, doi: 10.1016/j.achaem.2015.07.044.

21. Goldman M, Magnussen K, Gorlin J, et al. International Forum regarding practices related to donor haemoglobin and iron. Vox Sang. 2016; 111(4): 449-455, doi: 10.1111/vox.12431, indexed in Pubmed: 27564140.

22. Vuk T, Magnussen K, De Kort W, et al. International forum: an investigation of iron status in blood donors. Blood Transfus. 2017; 15(1): 20-41, doi: 10.2450/2016.0101-16, indexed in Pubmed: 27643753.

23. Vassallo R, Goldman M, Germain M, et al. BEST Collaborative. Preoperative Autologous Blood Donation: Waning Indications in an Era of Improved Blood Safety. Transfus Med Rev. 2015; 29(4): 268-275, doi: 10.1016/j.tmrv.2015.04.001, indexed in Pubmed: 26006319.

24. European Directorate for the Quality of Medicines and HealthCare (EDQM). Guide to the preparation, use and quality assurance of blood components: recommendation No. R (95) 15, wyd. 20, 2020.

25. Główny Urząd Statystyczny, Komitet Redakcyjny. Rocznik demograficzny 2017.

26. Główny Urząd Statystyczny, Komitet Redakcyjny. Rocznik demograficzny 2015.

27. Główny Urząd Statystyczny, Komitet Redakcyjny. Rocznik demograficzny 2016.

28. Komitet Redakcyjny Głównego Urzędu Statystycznego. Rocznik demograficzny 2019.

29. NICE. Blood transfusion. NICE guideline. Published: 18 November 2015. nice.org.uk/guidance/ng24 [Online].

30. Klein AA, Arnold P, Bingham RM, et al. AAGBI guidelines: the use of blood components and their alternatives 2016. Anaesthesia. 2016; 71(7): 829-842, doi: 10.1111/anae.13489, indexed in Pubmed: 27062274.

31. Estcourt LJ. Why has demand for platelet components increased? A review. Transfus Med. 2014; 24(5): 260-268, doi: 10.1111/ tme.12155, indexed in Pubmed: 25327286.

32. Simancas-Racines D, Osorio D, Martí-Carvajal AJ, et al. Leukoreduction for the prevention of adverse reactions from allogeneic blood transfusion. Cochrane Database Syst Rev. 2015(12): CD009745, doi: 10.1002/14651858.CD009745.pub2, indexed in Pubmed: 26633306.

33. Heitmiller ES, Hill RB, Marshall CE, et al. Blood wastage reduction using Lean Sigma methodology. Transfusion. 2010; 50(9): 1887-1896, doi: 10.1111/j.1537-2995.2010.02679.x, indexed in Pubmed: 20456700.

34. Apelseth TØ, Bruserud Ø, Wentzel-Larsen T, et al. In vitro evaluation of metabolic changes and residual platelet responsiveness in photochemical treated and gamma-irradiated single-donor platelet concentrates during long-term storage. Transfusion. 2007; 47(4): 653-665, doi: 10.1111/j.1537-2995.2007.01167.x, indexed in Pubmed: 17381624.

35. Rosiek A, Tomaszewska A, Lachert E, et al. Działalność jednostek organizacyjnych służby krwi w Polsce w 2016 roku. J Transf Med. 2017; 10(4): 113.

36. Rosiek A, Tomaszewska A, Lachert E, et al. Działalność jednostek organizacyjnych służby krwi w Polsce w 2017 roku. J Transf Med. 2018; 11(4): 113-130.

37. Rosiek A, Tomaszewska A, Lachert E, et al. Działalność jednostek organizacyjnych służby krwi w Polsce w 2015 roku. J Transf Med. 2016; 9(4): 1-18.

38. Rosiek A, Tomaszewska A, Lachert E, et al. Działalność jednostek organizacyjnych służby krwi w Polsce w 2018 roku. J Transf Med. 2019; 12(4): 127-143.

39. Antoniewicz-Papis J, Łaguna P. et al. Standard Pracy Komitetu Transfuzjologicznego 2020. epub ISBN - 978-83-949959-2-8, mobi ISBN- 978-83-949959-3-5, pdf ISBN - 978-83-949959-1-1.

40. Jones JM, Sapiano MRP, Savinkina AA, et al. Slowing decline in blood collection and transfusion in the United States - 2017. Transfusion. 2020; 60 Suppl 2: S1-S9, doi: 10.1111/trf.15604, indexed in Pubmed: 32086817.

41. Sapiano MRP, Jones JM, Savinkina AA, et al. Supplemental findings of the 2017 National Blood Collection and Utilization Survey. Transfusion. 2020; 60 Suppl 2: S17-S37, doi: 10.1111/ trf.15715, indexed in Pubmed: 32134122.

42. Savinkina AA, Haass KA, Sapiano MRP, et al. Transfusion-associated adverse events and implementation of blood safety measures - findings from the 2017 National Blood Collection and Utilization Survey. Transfusion. 2020; 60 Suppl 2: S10-S16, doi: 10.1111/trf.15654, indexed in Pubmed: 32134123.

43. Yoshida T, Prudent M, D'alessandro A. Red blood cell storage lesion: causes and potential clinical consequences. Blood Transfus. 2019; 17(1): 27-52, doi: 10.2450/2019.0217-18, indexed in Pubmed: 30653459.

44. Mueller MM, Van Remoortel H, Meybohm P, et al. Patient Blood Management: Recommendations From the 2018 Frankfurt Consensus Conference. JAMA. 2019; 321(10): 983-997, doi: 10.1001/ jama.2019.0554, indexed in Pubmed: 30860564.

45. Mueller MM, Van Remoortel H, Meybohm HP, et al. Patient Blood Management - Recommendations From The International Consensus Conference, Frankfurt/Main, Germany. Vox Sang. 2020; 115 (S1-The 36th International ISBT Congress, Virtual meeting, 12-16 December 2020): 25. 